DEPÓSITO LEGAL ppi $201502 Z U 4666$

Esta publicación científica en formato digital

es continuidad de la revista impresa

ISSN 0041-8811

DEPÓSITO LEGAL pp 76-654

\title{
Revista de la
}

Universidad del Turlia

Fundada en 1947

por el Dr. Jesús Enrique Lossada

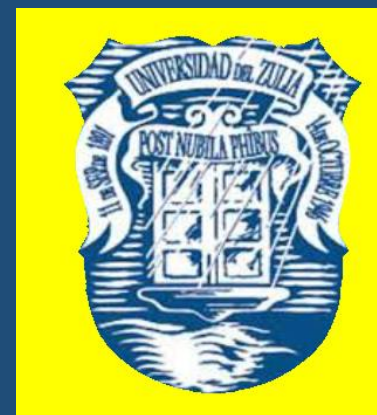

\section{Ciencias}

\section{Exactas}

Naturales

y de la Salud

\section{Aีัต 11 No $\mathbf{3 0}$ \\ Mayo - Agosto 2020 \\ Tercera ippoca \\ Maracaibo-Venezuela}




\title{
The share of health care spending in the structure of GDP as a criterion for the healthcare system effectiveness
}

\author{
Danil Alekseevich Zyukin * \\ Anna Yurievna Bystritskaya ** \\ Artem Alekseevich Golovin *** \\ Olga Vladimirovna Vlasova ****
}

ABSTRACT

Effective work of the healthcare system is becoming increasingly important in modern conditions, which actualizes the task of finding tools to increase the effectiveness of its functioning; this should ultimately lead to a decrease in morbidity and an increase in life expectancy. One of the main criteria for social development in modern conditions is the share of health care spending as a percentage of GDP; since this reflects the degree of attention and concern of the state about the health and life of citizens. The research hypothesis states that the share of health care costs does not affect the quality of the health care system, which is expressed in the average life expectancy of the population. To confirm the hypothesis, an analysis was made of the degree of influence of the share of expenditures on health care development on GDP on average life expectancy in the context of countries using a simple pair correlation and correlation between ranks; A cluster analysis of the countries was also carried out on the basis of their grouping according to the level of health spending as a percentage of GDP. It has been established that there is no connection between the share of health expenditures from GDP in countries and average life expectancy in them, which confirms the failure to use this indicator as a criterion for assessing the development of the health system. A cluster analysis of the countries under consideration showed that the effectiveness of the health care system is a complex category, depending not only on the level of state funding, but also on a number of other aspects.

KEYWORDS: healthcare, WHO, ranking of countries, share of healthcare expenditures, life expectancy, healthcare system efficiency.

*Candidate of Economic Sciences, Senior Researcher Kursk State Agricultural Academy named after I.I. Ivanov Russia, ORCID: https://orcid.org/0000-0001-8118-2907

* Candidate of Economic Sciences, Associate Professor, Head of the Department of Economics and Accounting Kursk State University. Russia.

*** Candidate of Economic Sciences, Associate Professor of the Department of Customs and the World Economy Southwestern State University. Russia ORCID: https:/orcid.org/0000$\underline{\text { 0001-6688-3561 }}$

**** Candidate of Economic Sciences, Associate Professor of the Department of Economics and Management Kursk State Medical University, Russia.

Recibido: 03/04/2020

Aceptado: 01/06/2020 


\section{La participación del gasto en salud en la estructura del PIB como criterio para la efectividad del sistema de salud}

RESUMEN

El trabajo efectivo del sistema de salud se está volviendo cada vez más importante en las condiciones modernas, lo que actualiza la tarea de encontrar herramientas para aumentar la efectividad de su funcionamiento; esto debería conducir a una disminución de la morbilidad y un aumento de la esperanza de vida. Uno de los criterios principales para el desarrollo social en las condiciones modernas es la proporción del gasto en atención de salud como porcentaje del PIB; ya que esto refleja el grado de atención y preocupación del Estado sobre la salud y la vida de los ciudadanos. La hipótesis de la investigación establece que la parte de los costos de atención médica no afecta la calidad del sistema de atención médica, que se expresa en la expectativa de vida promedio de la población. Para confirmar la hipótesis, se realizó un análisis del grado de influencia de la participación del gasto en el desarrollo de la atención de salud en el PIB sobre la esperanza de vida promedio en el contexto de los países que utilizan una correlación simple de pares y una correlación entre los rangos. También se realizó un análisis de conglomerados de los países sobre la base de su agrupación de acuerdo con el nivel de gasto en salud como porcentaje del PIB. Se ha establecido que no existe una conexión entre la participación del gasto en salud del PIB en los países y la esperanza de vida promedio en ellos, lo que confirma la falta de uso de este indicador como criterio para evaluar el desarrollo del sistema de salud. Un análisis de conglomerados de los países considerados mostró que la efectividad del sistema de atención de salud es una categoría compleja, que depende no solo del nivel de financiación estatal, sino también de otros aspectos.

PALABRAS CLAVE: asistencia sanitaria, OMS, clasificación de países, porcentaje de gastos en asistencia sanitaria, esperanza de vida, eficiencia del sistema sanitario

\section{Introduction}

The most important goal of state health policy at the present stage is to improve the demographic situation, the state of public health, and to ensure the availability and quality of medical care for citizens. Effective work of the health system is becoming increasingly important: the emergence of a new coronavirus infection in 2019 and its transformation into a world pandemic in 2020 showed that the health care system in most countries was not perfect and was not ready for such threats, which already led to the deaths of tens of thousands of people (Podgalo et al., 2019). In this regard, the task of searching for tools to increase the effectiveness of its functioning is being updated, which ultimately should lead to a decrease in the incidence and increase in average life expectancy (Tagaeva and Kazantseva, 2016). 
The most important characteristic of human potential and state of health can be considered an indicator of life expectancy. Life expectancy is considered as one of the basic indicators of socio-economic well-being of the population (Tuaeva and Sugarova, 2013; Polezharova et al., 2020). Tracking the dynamics of average life expectancy in the country and comparing the results by region and district helps identify problem areas in which the demographic problem is most acute. This makes it possible to respond in the framework of regional and national social policies (Vlasova, 2017).

Bloomberg experts consider the life expectancy of the average citizen as the main indicator (60\% of weight) when assessing the level of effectiveness of healthcare systems (Russia Became the Last in Health Care Efficiency Rating, 2016). Other indicators are government spending on health as a share of GDP per capita and the cost of per capita medical services. The first of these indicators is a reflection of the degree of attention and concern of the state to the health and life of citizens (Panova, 2015). Therefore, the prevailing share of health care expenditures in the structure of GDP in comparison with developed countries criticizes the liberal part of Russian society, which considers the level of the indicator not sufficient to ensure the provision of quality medical care accessible to all citizens of the country. Sergeeva NM, comparing this indicator of Russia with the countries of Europe, notes that its level is stably inferior to all but Ukraine in recent years (Sergeeva, 2018). There are undoubtedly differences in the health systems that have developed in the world; this figure will be naturally higher in countries with a larger private sector (Perkhov and Lutsko, 2019).

The share of government spending is considered the main criterion for the development of healthcare; the health system cannot exist solely on the basis of budgetary funds (Zyukin et al., 2019). The experience of the most developed European countries confirms this; there is a high life expectancy of the population, but a significant part of medical expenses is transferred to insurance medical organizations or carried out at the expense of the patient (Travnev, 2017). There is also a fair opinion that the achievement of healthcare efficiency while ensuring a high life expectancy is the result of the effective work of all elements of the system: from the necessary level of financing to the rational use of available resources, as well as increasing the motivation of medical personnel to work and conscientious performance of their duties (Kuznetsov, 2019; Muñoz, 2019). 
REVISTA DE LA UNIVERSIDAD DEL ZULIA. 3ª época. Año 11 N 30, 2020

Danil Alekseevich Zyukin et al. /// The share of healt care spending in the structure ...352-363

\section{Theoretical basis}

The effectiveness of the functioning of health systems is most often determined on the basis of the average life expectancy of the population, since it is believed that the more efficient the health system is, the higher the life expectancy of the population in a certain territory (Kadyrov et al., 2019). However, effectiveness is affected by a system of many factors of different nature of action. The relative importance of healthcare as an economic sphere is manifested through the indicator of the share of healthcare expenditures in the structure of GDP. Our position is based on the fact that this indicator among the countries is not an objective criterion for the work of the health care system, and therefore it is also not able to influence life expectancy. The share of health care expenditures in the GDP structure is not indicative of Russia as a large country in terms of population and especially in geographical size, which still retains elements of Soviet state medicine. At the same time, other, especially the general improvement in the economic situation in the country, which has slowed down significantly in recent years, have become the priority reasons for ensuring an increase in the life expectancy of the population of Russia. Therefore, the research hypothesis says that the share of health care spending does not affect the quality of the health care system, which is expressed in the average life expectancy of the population.

\section{Methodology}

The work used data published by the Center for Humanitarian Technologies, reflecting the rating among 183 countries in terms of health care spending (The rating of the countries of the world in terms of health spending, 2006-2020) and average life expectancy of the population (Rumyantseva, 2018). To confirm the hypothesis, an analysis was made of the degree of influence of the share of health care spending in the GDP structure on average life expectancy in the context of countries using a simple pair correlation and correlation between ranks based on the construction of data scattering diagrams. A cluster analysis was also carried out, on the basis of which a grouping was made among countries by the level of health spending as a percentage of GDP. The number of groups was determined based on the Sturgess formula. A confirmation of the hypothesis that there is no connection between the share of health care spending in the structure of GDP and life expectancy is the insignificance of the pair correlation coefficient, the inadequacy of the approximation model for their 
relationship and the absence of a logical connection in the groups obtained depending on the level of the regressor factor.

\section{Results}

An assessment of the impact of the share of health care expenditures on average life expectancy in the context of 183 countries on the basis of constructing a dispersion diagram showed that there is no stable correlation between these indicators. This is confirmed by the results obtained, since the direction and compression of the cluster points relative to the regression line emphasizes the absence of a significant correlation between the studied data series (Figure 1).

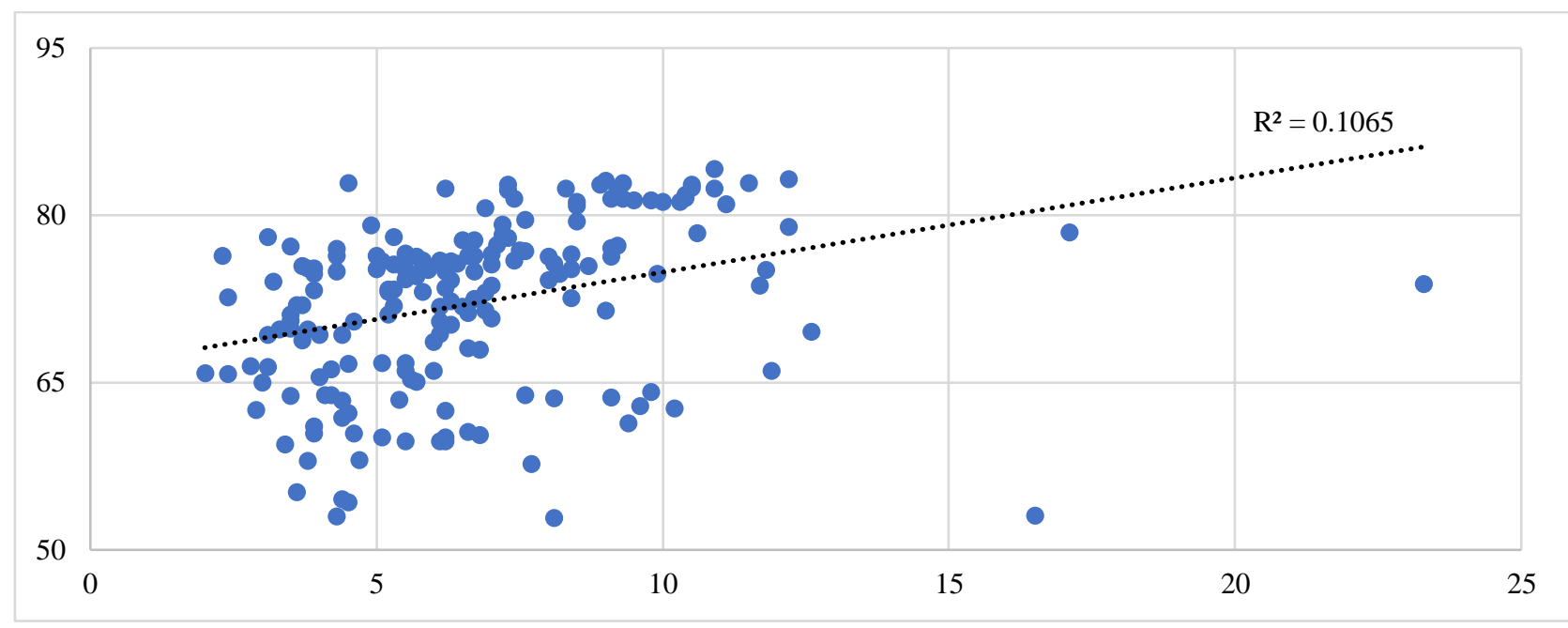

Figure 1 . Assessment of the relationship between the average life expectancy and the level of health expenditure on GDP in the context of 183 countries in 2018

An analysis of the correlation of the ranks of the studied indicators also confirmed the absence of a relationship between life expectancy and the level of health care spending in different countries; This is evidenced by the scattering diagram obtained, on which the cluster points relative to the regression line are randomly located and have a large spread (Figure 2). 


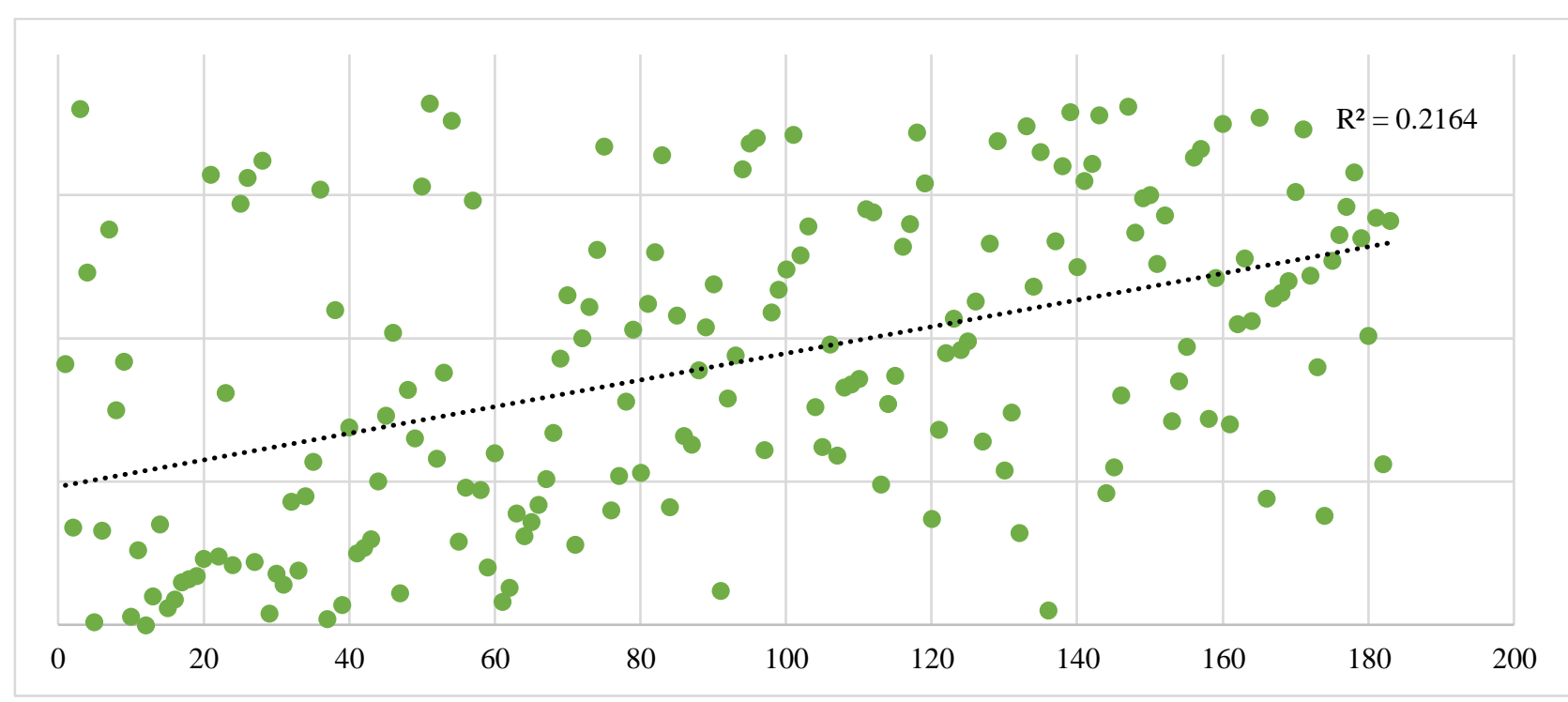

Figure 2. Assessment of the relationship between the ranks in the context of 183 countries by average life expectancy and the level of health care expenditures from GDP in 2018

All countries were divided into 8 groups during cluster analysis based on the Sturgess formula. During the clustering process, 3 countries were excluded from the sample - Sierra Leone, the USA and the Marshall Islands, in which the level of health expenditures was significantly separated from other countries and amounted to $16.5 \%, 17.1 \%$ and $23.3 \%$, time, as in other countries, the variation of the studied indicator ranges from $2-12.6 \%$.

As a result, the first group with the lowest level of expenditures (2-3.3\%) included 12 countries, most of which belong to East Asia and Africa and have a low level of socioeconomic development (the exception is Qatar). The average group level of health spending is $3 \%$, and the average life expectancy in these countries is 69 years. The second group, where the level of health spending varies from 3.3-4.7\%, includes 39 countries from different continents of the world and having different levels of socio-economic development. At the same time, the average level of health care spending in the group is $4.0 \%$, and the average life expectancy is 67 years, which is lower than in the first group. As a result of clustering, 31 countries, including Russia, were included in the third group of countries with a level of health spending in the range of 4.7-6.0\%; the average level of health expenditures from GDP in which was $5 \%$, and the average life expectancy was 72 years.

The fourth group is the largest and includes 41 states of the world, where the share of health care spending varies between 6-7.3\% of GDP, and the average group spending level was $7 \%$ with an average life expectancy of 81 years, which is the highest value among all 
REVISTA DE LA UNIVERSIDAD DEL ZULIA. 3ª época. Año 11 N 30, 2020

Danil Alekseevich Zyukin et al. /// The share of healt care spending in the structure ...352-363

clusters. The fifth group included 20 countries with different levels of socio-economic development with a share of health expenditures of $7.3-8.6 \%$ of GDP and an average life expectancy of 74 years. The sixth group of countries included 19 countries, including many countries in Europe, where the level of health spending is 8.6-10\% of GDP. At the same time, the average group expenditure level is 9\%, and the average life expectancy is only 76 years. 11 countries were included in the seventh group of countries with a fairly high level of health care spending, where health care spending varies between 10-11.3\%, and their average life expectancy is 80 years (Table 1 ).

Table 1. Cluster analysis of 183 countries by level of health spending in 2018

\begin{tabular}{|c|c|c|c|c|}
\hline 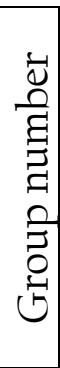 & $\begin{array}{l}\text { The number of } \\
\text { countries and } \\
\text { the interval of } \\
\text { the group by the } \\
\text { share of health } \\
\text { spending in } \\
\text { GDP }\end{array}$ & Country & $\begin{array}{l}\text { The average } \\
\text { value of } \\
\text { health } \\
\text { spending, } \\
\text { in\% of GDP }\end{array}$ & $\begin{array}{l}\text { Life } \\
\text { expectan } \\
\text { cy, years }\end{array}$ \\
\hline 1 & $\begin{array}{c}2,0-3,3 \% \\
(12 \text { countries })\end{array}$ & $\begin{array}{l}\text { Papua New Guinea, Brunei, Bangladesh, } \\
\text { Laos, Pakistan, Angola, Eritrea, Qatar, } \\
\text { Indonesia, Gabon, Venezuela }\end{array}$ & 3,0 & 69 \\
\hline 2 & $\begin{array}{c}3,3-4,7 \% \\
(39 \text { countries) }\end{array}$ & $\begin{array}{l}\text { Equatorial Guinea, UAE, Kazakhstan, } \\
\text { Bhutan, Fiji, Djibouti, Saint Vincent and } \\
\text { the Grenadines, Nigeria, Thailand, } \\
\text { Vanuatu, India, Malaysia, Mongolia, } \\
\text { Mali, Sri Lanka, Kuwait, Seychelles, } \\
\text { Benin, DRC, Timor-Leste, Ethiopia, } \\
\text { Tanzania, Guyana, Mauritania, Oman, } \\
\text { Turkey, Antigua and Barbuda, CAR, } \\
\text { Philippines, Ghana, Gambia, Cote } \\
\text { d'Ivoire, Singapore, Kenya, Zambia, } \\
\text { Chad, Congo, Egypt, Cameroon }\end{array}$ & 4,0 & 67 \\
\hline 3 & $\begin{array}{c}4,7-6,0 \% \\
\text { (31 countries) }\end{array}$ & $\begin{array}{l}\text { Bahrain, China, Romania, Peru, } \\
\text { Myanmar, Mozambique, Grenada, Cape } \\
\text { Verde, Solomon Islands, Dominic, Saint } \\
\text { Lucia, Tonga, Russia, Haiti, Mexico, } \\
\text { Samoa, Jordan, Senegal, Botswana, } \\
\text { Guinea, Yemen, Vietnam , Mauritius, } \\
\text { Saudi Arabia, Saint Kitts and Nevis, } \\
\text { Sudan, Morocco, Guatemala, Colombia, } \\
\text { Sao Tome and Principe, Madagascar }\end{array}$ & 5,0 & 72 \\
\hline 4 & $\begin{array}{c}6,0-7,3 \% \\
(41 \text { countries) }\end{array}$ & $\begin{array}{l}\text { Jamaica, Suriname, Belize, Cambodia, } \\
\text { Guinea-Bissau, Luxembourg, Latvia, }\end{array}$ & 7,0 & 81 \\
\hline
\end{tabular}


REVISTA DE LA UNIVERSIDAD DEL ZULIA. 3ª época. Año 11 N 30, 2020

Danil Alekseevich Zyukin et al. /// The share of healt care spending in the structure ...352-363

\begin{tabular}{|c|c|c|c|c|}
\hline & & $\begin{array}{l}\text { Dominican Republic, Uganda, Burundi, } \\
\text { Niger, Macedonia, Belarus, Uzbekistan, } \\
\text { Nepal, Bahamas, Poland, Trinidad and } \\
\text { Tobago, Algeria, Kyrgyzstan, } \\
\text { Turkmenistan, Togo, Estonia, Albania, } \\
\text { Lithuania, Ukraine, Rwanda, Burkina } \\
\text { Faso, Cyprus, Azerbaijan, Bolivia, } \\
\text { Tunisia, Barbados, El Salvador, } \\
\text { Tajikistan, Slovakia, Czech Republic, } \\
\text { Croatia, South Korea, Israel, Panama }\end{array}$ & & \\
\hline 5 & $\begin{array}{c}7,3-8,6 \% \\
(20 \text { countries })\end{array}$ & $\begin{array}{l}\text { Ireland, Hungary, Argentina, Costa Rica, } \\
\text { Montenegro, Comoros, Swaziland, } \\
\text { Lebanon, Paraguay, Iran, South Africa, } \\
\text { Lesotho, Bulgaria, Iceland, Ecuador, } \\
\text { Honduras, Georgia, Greece, Slovenia, } \\
\text { Chile }\end{array}$ & 8,0 & 74 \\
\hline 6 & $\begin{array}{c}8,6-10,0 \% \\
(19 \text { countries })\end{array}$ & $\begin{array}{l}\text { Nicaragua, Italy, Spain, Moldova, } \\
\text { Portugal, Uruguay, Serbia, Namibia, New } \\
\text { Zealand, Bosnia and Herzegovina, } \\
\text { Australia, Malta, Zimbabwe, Finland, } \\
\text { Liberia, United Kingdom, Malawi, } \\
\text { Armenia, Belgium }\end{array}$ & 9,0 & 76 \\
\hline 7 & $\begin{array}{c}10,0-11,3 \% \\
(11 \text { countries })\end{array}$ & $\begin{array}{l}\text { Afghanistan, Denmark, Austria, Andorra, } \\
\text { Netherlands, Canada, Norway, Maldives, } \\
\text { Japan, Sweden, Germany }\end{array}$ & 11,0 & 80 \\
\hline 8 & $\begin{array}{c}11,3-12,6 \% \\
(10 \text { countries })\end{array}$ & $\begin{array}{l}\text { France, Palau, Brazil, Kiribati, } \\
\text { Switzerland, Cuba, Micronesia Sierra } \\
\text { Leone, USA, Marshall Islands }\end{array}$ & 12,0 & 76 \\
\hline
\end{tabular}

Source: made by the author based on data from the Center for Humanitarian Technologies (The rating of the countries of the world in terms of health spending, 2006-2020; Rating of countries in terms of life expectancy, 2016-2020).

The eighth group of countries with the highest expenditures on healthcare development included 10 entities, among which 7 have healthcare expenditures ranging from $11.3-12.6 \%$, as well as 3 countries with extremely high healthcare expenditures (Sierra Leone, USA and Marshall Islands). Moreover, the average level of health spending among 7 countries is $12 \%$, and the average life expectancy is only 76 years. Despite the fact that health care spending in Sierra Leone is about 16.5\%, the average life expectancy in this African republic is only 53 years, which confirms the hypothesis that the share of health care spending is not a determining factor in the quality of the system health care and, accordingly, does not significantly affect the life expectancy of the population. In the United States, despite 17.1\% 
REVISTA DE LA UNIVERSIDAD DEL ZULIA. 3ª época. Año 11 N 30, 2020

Danil Alekseevich Zyukin et al. /// The share of healt care spending in the structure ...352-363

of healthcare costs, life expectancy is 78.5 years, although, for example, this indicator in Japan with a spending level of $10.9 \%$ is 84.2 years. The highest level of health spending is observed in the Marshall Islands (23.2\%), but the average life expectancy is only 73.9 years.

\section{Discussions}

The uneven development of health systems in different countries is revealed by ratings on indicators such as life expectancy, the number of healthy people in society, and the effectiveness of medical care (Rumyantseva, 2018). However, the ratings of countries on the effectiveness of the health system in practice are still not always indicative. For example, according to a Bloomberg rating in 2016 (Lu Wei and Del Giudice), Italy took the first place, which was most affected by the consequences of the spread of COVID-19.

Many scientists agree that life expectancy is an important indicator of the effectiveness of the health system. At the same time, the share of health care expenditures in the context of assessing the quality of work of this system reflects only the attention of a particular state to its healthcare system as an important component of the social sphere (Poklonova et al., 2015).

Despite the fact that the World Health Organization annually publishes ratings of countries according to the level of health care spending, this indicator is not an objective criterion for international comparisons, since all countries have different levels of GDP, area, size and socio-demographic characteristics of the population (Travnev, 2017). The indicator of per capita health expenditures is more objective from the point of view of assessing the health system, since it is calculated in countries in a single currency (most often in US dollars), and the determination of its size per inhabitant makes it possible to take into account the differentiation of countries by area and population (Diaghileva, 2014).

So, Obrizan M. and Wehby G.L. revealed the heterogeneity of the results in their study of the impact of health care spending in countries on life expectancy in 2006-2011 using quantile regression. Their results suggest that increasing health care costs in countries with low life expectancy can have an important impact on life expectancy and significantly reduce global inequality in life expectancy and development by reducing the distribution of life expectancy in the world (Obrizan and Wehby, 2018). 
At the present stage of development, the degree of state participation in the policy of financing the health system has begun to change, but there is some convergence in policies adopted in different countries to improve financial incentives and encourage the effective use of medical services. The key factor for success in the competition of hospitals is changes in the efficiency of hospitals, and not the attitude to public or private ownership, which also strongly determines the share of health care expenditures in the structure of GDP as practice shows (Stabile and Thomson, 2014).

The main problem of ensuring the growth of life expectancy of the population of Russia is the use of outdated treatment technologies (for example, surgical intervention instead of more effective therapy), the lack of a focus on healthcare for the recovery of patients, the underdevelopment of preventive medicine, violation of citizens' rights (tacit focus on saving) in the manner of providing free medical care (access to diagnostic equipment, prescribing procedures, issuing free medicines) (Rumyantseva, 2018). The present value of future medical expenses is an important determining factor in decisions made over time, such as financing long-term medical care, investment in fixed assets (Ewing et al., 2003). In most Russian regions, this approach to building a business in the healthcare system is still not relevant, so the real cost of medical services is difficult to assess, which determines less involvement of business entities in this sphere in the country's GDP. Scenario planning tools are poorly used, which are necessary for the system to assess the dynamics of the impact of new technologies, such as big data \& cloud \& in healthcare industry (Akhlaghinia et al., 2019).

\section{Conclusion}

The research confirms the hypothesis that the share of government spending on GDP does not affect the average life expectancy of the population as one of the most important criteria for the effectiveness of the health system. Based on the result of the correlation analysis carried out in the context of 183 countries, it was found that there is no connection between the share of health expenditures from GDP in countries and average life expectancy, which confirms the failure to use this indicator as a criterion for assessing the development of the health system. A cluster analysis of the countries under consideration showed that the highest life expectancy ( 81 years) is observed in those countries where the average level of health spending is about $7 \%$. Life expectancy is not high in countries where health spending 
REVISTA DE LA UNIVERSIDAD DEL ZULIA. 3ª época. Año 11 N 30, 2020

Danil Alekseevich Zyukin et al. /// The share of healt care spending in the structure ...352-363

is the highest share of GDP. This allows us to conclude that the effectiveness of the health care system is a complex category, depending not only on the level of state funding, but also on a number of other aspects. Since ensuring the high efficiency of national health systems is one of the priority tasks in modern conditions in modern conditions, the search for mechanisms to achieve it is an important area. Currently, WHO does not have a unified methodology for the objective assessment of the effectiveness of countries' health systems, which complicates the task of identifying and systematizing existing social problems in order to develop measures to solve them.

\section{References}

Akhlaghinia, N., Rajabzadeh, A., Yazdian, A., Moghbel, A. (2019). Scenario planning for emergent technology (big data \& cloud) in healthcare industry. Amazonia Investiga, 7 (15), 299-305.

Diaghileva, N.V. (2014). The effectiveness of public spending on health services. Bulletin of the Orenburg State Agrarian University, 6 (50), 205-208.

Ewing, B.T., Piette, M.J., Payne, Ja.E. (2003). Forecasting medical net discount rates. Journal of Risk \& Insurance, 70 (1), 85.

Kadyrov, F.N., Obukhova, O.V., Brutova, A.S. (2019). Health care financing in 2019: new priorities and channels for the movement of funds. Health Care Manager, 1, 70-78.

Kuznetsov, V.V. (2019). Modern aspects of the study of the effectiveness of healthcare to improve the quality of life of the population. Quality and life, l (21), 84-89.

Lu Wei, Del Giudice V. Italy's Struggling Economy Has World's Healthiest People. Available at: https:/www.bloomberg.com/news/articles/2017-03-20/italy-s-struggling-economy-hasworld-s-healthiest-people.

Muñoz, O. (2019). Cultura, gestión pública, gerencia y sistema de relacionamiento, Revista Latinoamericana de Difusión Científica, 1 (1), 68-83.

Obrizan, M., Wehby, G.L. (2018). Health expenditures and global inequalities in longevity. World Development, 28-36.

Panova, L.V. (2015). Health care financing as a contextual health factor. Petersburg Sociology Today, 6, 384-407.

Perkhov, V.I., Lutsko, V.V. (2019). Macroeconomic spending on healthcare in Russia and abroad. Modern problems of healthcare and medical statistics, 2, 334-345. 
REVISTA DE LA UNIVERSIDAD DEL ZULIA. 3ª época. Año 11 N 30, 2020

Danil Alekseevich Zyukin et al. /// The share of healt care spending in the structure ...352-363

Podgalo, D.D., Sokolova, M.G., Atroshchenko, A.M. (2019). Health problems in the Russian Federation and ways to solve them. Economics and production organization efficiency, 30, 74-80.

Poklonova, E.V., Starodub, V.A., Zagora, I.P. (2015). The costs of social policy: status and trends. Economics and Entrepreneurship, 11-2 (64), 112-117.

Polezharova, L. V.; Goncharenko, M. A.; Gryechishkin, A. V. (2020). International tax models towards multinational companies from the perspective of national welfare, Revista de la Universidad del Zulia, ll (29), 337-366.

Rating of countries in terms of life expectancy (2006-2020). The Humanitarian Encyclopedia: Research. Center for Humanitarian Technologies. Available at: https://gtmarket.ru/ratings/life-expectancy-index/life-expectancy-index-info.

Rumyantseva, E.E. (2018). Monitoring national health systems. World economy and international relations, 62 (2), 92-99.

Russia Became the Last in Health Care Efficiency Rating (2016). RBC. Available at: http://www.rbc.ru/society/29/09/2016/57ecd9499a79476f928bb8f.

Sergeeva, N.M. (2018). Comparative assessment of health care costs in Russia and European countries. Azimuth of scientific research: economics and management, 7 (3, 24), 256-259.

Stabile, M., Thomson, S. (2014). The changing role of government in financing health care: an international perspective. Journal of Economic Literature, 52 (2), 480-518.

Tagaeva, T.O., Kazantseva, L.K. (2016). Modern problems of public health and healthcare in Russia. Transactions of Novosibirsk State University of Architecture and Civil Engineering (Sibstrin), 19 (3, 63), 191-201.

The rating of the countries of the world in terms of health spending (2006-2020). The Humanitarian Encyclopedia: Research. Center for Humanitarian Technologies. Available at: https://gtmarket.ru/ratings/expenditure-on-health/info.

Travnev, L.N. (2017). Social expenditures of the state and the search for new instruments for financing social policy. Economics: yesterday, today, tomorrow, 7 (2A), 5-17.

Tuaeva, L.A., Sugarova, I.V. (2013). The effectiveness of spending on the health system. Terra Economicus, 11 (3-3), 94-97.

Vlasova, O.V. (2017). The study of life expectancy in the Central Federal District. Karelian Scientific Journal, 6 (4, 21), 335-337.

Zyukin, D.A., Belyaev, S.A., Vlasova, O.V., Nadzhafova, M.N., Reprintseva, E.V., Sergeeva, N.M. (2019). On the trends in the expansion of the market of paid medicine in the federal districts of the Russian Federation. Vestnik NGIIE, 3 (94), 62-73. 